\title{
Analisis Kesulitan Penguasaan Konsep Mahasiswa pada Topik Rotasi Benda Tegar Dan Momentum Sudut
}

\author{
Lalu Amnirullah \\ Universitas Negeri Malang \\ Jl. Surabaya 6, Malang \\ laluamnirullah@ymail.com
}

\begin{abstract}
Abstrak - Penelitian ini bertujuan untuk mengetahui kesulitan penguasaan konsep mahasiswa pada topik rotasi benda tegar dan momentum sudut. Penelitian ini merupakan penelitian deskriptif eksploratif yaitu penggambaran keadaan suatu fenomena. Terdapat 8 indikator pembelajaran yang digunakan untuk mendeskripsikan dan mengeksplorasi kesulitan-kesulitan mahasiswa terhadap penguasaan konsep rotasi benda tegar dan momentum sudut. Kesulitan tersebut diketahui melalui tes penguasaan konsep yang diberikan setelah pembelajaran berlangsung. Penelitian ini melibatkan mahasiswa pendidikan fisika semester 1 yang mengambil mata kuliah fisika dasar 1. hasil penelitian menunjukkan bahwa kesalahan-kesalahan umum yang dilakukan oleh siswa dalam menyelesaikan soal konsep yang diberikan yaitu kesulitan tertinggi mahasiswa didapatkan pada hubungan kecepatan sudut dan torsi sedangkan penguasaan konsep yang baik didapatkan pada pembahasan momen inersia.
\end{abstract}

Kata kunci: penguasaan konsep, rotasi, momentum sudut

\begin{abstract}
This Research aims to determine the difficulty mastery of concepts students on the topik of rigid body rotation and angular momentum. Research conducted an explorative descriptive study. There are 8 learning indicators used to describe and explore the difficulties students to mastery of the concept of a rigid body rotation and angular momentum. The difficulties identified through tests mastery of concepts is given after learning takes place. This research involves students 1st semester of physics education that takes the basic physics course 1. research showed that common mistakes made by students in solving a given concept that students obtained the highest difficulty relationship angular velocity and torque, while a good mastery of concepts found in the discussion of the moment of inertia.
\end{abstract}

Key words: mastery of concepts, rotation angular momentum

\section{PENDAHULUAN}

Fisika adalah pembelajaran yang mengutamakan penguasaan konsep. Penguasaan konsep menunjukkan siswa menguasai materi-materi fisika dengan baik. Mengetahui kesulitan siswa tentang berbagai konsep fisika penting dalam menentukan strategi pembelajaran untuk mengurangi atau menghilangkan kesulitan tersebut [1]. Salah satu materi fisika yang menjadi kesulitan siswa adalah konsep dinamika rotasi [1][2] [3].

Rotasi adalah materi fisika yang kompleks dan mendasar. Pembahasan Rotasi mencakup torsi, moment inersia, energi kinetik rotasi, kecepatan liner, dan memontum sudut [5][6][7]. Penelitian yang dilakukan oleh Rimoldini (2005) menunjukkan kesulitan siswa dalam menganalisis konsep moment inersia, percepatan sudut, torsi dan hubungan dengan energi kinetik rotasi benda tegar. Selain itu Escudero (2009) mengatakan bahwa kesulitan siswa tentang konsep rotasi terletak pada peranan moment inersia terhadap energi rotasi, dan pengaruh torsi terhadap percepatan sudut. Ketuntasan belajar di materi mendasar dalam hal ini rotasi, mempengaruhi kemampuan siswa untuk menguasai materi lebih lanjut [3]

Topik dasar gerak rotas dan momentum sudut adalah energi kinetik rotasi, momen inersia, torsi, hubungan torsi dan percepatan sudut, Energi kinetik total, energi kinetik pada benda yang bergelinding, hubungan momentum sudut dan linier, serta hukum kekekalan momentum sudut
[7]. sehingga dalam penelitian ini fokus pada kesulitan mahasiswa pada bahasan rotasi benda tegar dan momentum sudut pada materi fisika dasar.

\section{LANDASAN TEORI}

\section{A. Penguasaan Konsep}

Konsep merupakan buah pemikiran seseorang atau sekelompok orang yang dinyatakan dalam definisi sehingga melahirkan produk pengetahuan meliputi prinsip, hukum dan teori. Konsep dapat diperoleh dari fakta, peristiwa, pengalaman, melalui generalisasi dan berpikir abstrak [4]. Konsep dapat mengalami perubahan disesuaikan dengan fakta atau pengetahuan baru, sedangkan kegunaan konsep adalah untuk menjelaskan dan meramalkan.

konsep dapat diperoleh dengan dua cara, yaitu pembentukan konsep dan asimilasi konsep. Konsep merupakan buah pemikiran seseorang atau sekelompok orang yang dinyatakan dalam definisi sehingga melahirkan produk pengetahuan meliputi prinsip, hukum dan teori. Konsep dapat diperoleh dari fakta, peristiwa, pengalaman, melalui generalisasi dan berpikir abstrak. Konsep dapat mengalami perubahan disesuaikan dengan fakta atau pengetahuan baru, sedangkan kegunaan konsep adalah untuk menjelaskan dan meramalkan. 


\section{B. Rotasi Benda Tegar Dan Momentum Sudut}

Rotasi adalah adalah perputaran semua titik pada benda yang bergerak mengitari sumbu atau poros benda tersebut. Sebuah benda tegar (kaku dan homogen) berputar terhadap suatu sumbu akan tetap diam dalam ruang sehingga tidak ada energi kinetik yang berkaitan dengan gerak translasi. Benda tegar diartikan sebagai benda dengan bentuk tertentu yang tidak berubah bentuk, sehingga partikel-partikel pembentuknya berada pada posisi yang tetap relatif satu sama lain, sehingga ketika benda berotasi masing-masing partikel penyusun benda tersebut bergerak dalam ruang mengikuti lintasan lingkaran. Terdapat energi yang berkaitan dengan dengan rotasi benda tegar dan momentum sudut [7].

Dalam topik rotasi terdapat besaran baru yang tidak terdapat dalam gerak translasi diantaranya momen inersia, torsi, kecepatan sudut dan percepatan sudut, serta energi benda yang berotasi pada sebuah sumbu dikatakan memilki energi kinetik rotasi [5]

Momentum sudut merupakan besaran yang memainkan peran kunci dari dinamika rotasi. Dalam analogi prinsip kekealan momentum linier, ditemukan bahwa momentum sudut dari system adalah kekal jika tidak ada torsi dari luar yang bekerja pada sistem. Seperti hukum kekekalan momentum linier, hukum kekekalan momentum sudut adalah besaran yang menjadi dasar dari hukum fisika yang berlaku untuk system relativistik maupun sisitem kuantum

\section{METODE PENELITIAN}

Penelitian ini merupakan penelitian explorative descriptive bertujuan untuk menggambarkan keadaan suatu fenomena. Data yang digunakan adalah data hasil tes penguasaan konsep pada materi rotasi benda tegar dan momentum sudut setelah pembelajaran berlangsung. Penelitian ini dilakukan pada kelompok mahasiswa dalam satu kelas yang berjumalh 30 mahasiswa ( 25 perempuan dan 5 laki-laki) di jurusan pendidikan fisika kelas offering $\mathrm{b}$ yang sedang menempuh mata kuliah fisika dasar I di semester 1.

Tes yang diberikan terdiri dari delapan soal penguasaan konsep yang mewakili delapan bahasan dasar penguasaan konsep rotasi benda tegar dan momentum sudut. soal konsep berisikan tentang energi kinetik rotasi, momen inersia, torsi, hubungan torsi dan percepatan sudut, energi kinetik total, energi kinetik pada benda yang bergelinding, hubungan momentum sudut dan linier, dan hukum kekekalan momentum

Tes diberikan setelah pembelajaran topik bahasan rotasi benda tegar dan momentum sudut selesai. Bentuk tes yang diberikan adalah tes penguasaan konsep essay dengan tujuan mengeksplorasi kesalahan-kesalahan umum mahasiswa dalam tahapan penyelesaian dan hasil tes. Mahasiswa diberikan waktu selama 60 menit untuk menyelesaikan 8 soal konsep yang disediakan.

Hasil tes yang telah dikoreksi, diberi lebel benar dan poin 10 untuk jawaban yang benar secara keseluruhan. Jawaban yang salah dianalisis untuk menemukan pola kesalahan umum yang terdapat pada jawaban mahasiswa. Berikut tabel soal yang di berikan dalam tes :
Tabel 1. Soal penguasaan konsep

\begin{tabular}{ccc}
\hline No. & Soal penguasaan konsep & keterangan \\
\hline 1 & Energi kinetik rotasi & Soal 1 \\
2 & Momen inersia & Soal 2 \\
3 & Torsi & Soal 3 \\
4 & Hubungan torsi dan percepatan sudut & Soal 4 \\
5 & Energi kinetik total5 & Soal 5 \\
6 & Benda yang bergelinding & Soal 6 \\
7 & Hubungan momentum sudut dan linier & Soal 7 \\
8 & Hukum kekekalan momentum sudut & Soal 8 \\
\hline
\end{tabular}

\section{HASIL DAN PEMBAHASAN}

Penguasaan konsep mahasiswa tentang topik rotasi benda tegar dan momentum sudut memberikan gambaran tingkat pemahaman konsep yang dimiliki oleh mahasiswa. Gambaran penguasaan konsep mahasiswa dipengaruhi oleh kemampuan awal mahasiswa tentang gerak linier yang dibahas dalam bab-bab sebelumnya. Secara konseptual hubungan antara gerak rotasi dan gerak linier sangat fundamental sehingga ketika mahasiswa belum menguasai gerak linier dengan baik maka akan menyulitkan mahasiswa tersebut dalam pembahasan gerak rotasi.

Kesulitan umum mahasiswa adalah ketika memadukan besaran-besaran gerak linier dan gerak melingkar diantaranya peninjauan pengaruh massa dan momen inersia. Momen inersia sendiri merupakan besaran yang terbentuk dari besarnya massa dan kuadrat jari-jari, sehingga terdapat konsep baru yang tidak dibahas dalam gerak linier. Dengan pemahaman yang cukup pada materi gerak linier akan memudahkan asimilasi penguasaan konsep pada topik bahasan gerak melingkar.

Pada soal konsep pertama tentang energi kinetik rotasi, soal yang disajikan berupa dua buah silinder dengan massa yang berbeda dan kecepatan yang berbeda seperti yang terlihat pada Gambar 1. siswa yang menjawab dengan benar adalah 20 orang, sehingga terdapat 10 mahasiswa menjawab dengan jawaban yang keliru, tipe kesalahan yang dilihat anatara lain tidak dapat memberikan pengaruh massa dan kecepatan sudut dengan benar sehingga memiliki hasil perhitungan yang berbeda dari sebenarnya.

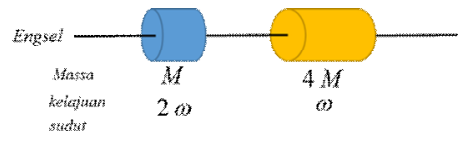

Gambar 1. Gambar soal konsep 1

Pada soal konsep momen inersia pada sebuah benda. Soal konsep yang disajikan adalah silinder homogen panjang dengan posisi putar yang berbeda seperti pada Gambar 2. dari 30 mahasiswa terdapat 24 siswa menjawab benar dan 6 siswa menjawab salah. Kesalahan umum mahasiswa terletak pada posisi pusat rotasi sebuah benda, sehingga ketika benda sama, mahasiswa beranggapan momen inersia sama untuk semua sumbu putar. 


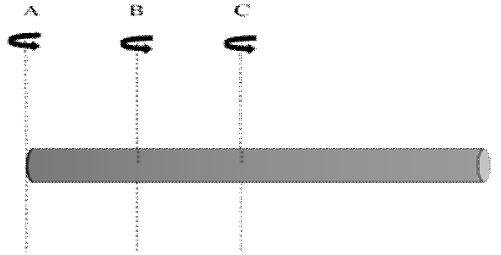

Gambar 2. Gambar soal konsep 2

Pada soal konsep torsi, torsi merupakan besaran yang memiliki peran sama dengan gaya $(\mathrm{F})$ pada gerak linier, namun memeliki prinsip yang berbeda. Torsi adalah besarnya gaya yang dipengaruhi oleh posisi gaya terhadap pusat rotasi (lengan gaya). Pada soal ini terdapat batang yang diputar dengan gaya yang sama namun terdapat variasi arah dan lengan gaya. Terdapat 7 mahasiswa memiliki jawaban keliru, soal konsep torsi seperti pada Gambar 3. umumnya mahasiswa tidak dapat membedakan peranan torsi dan peranan gaya, bahkan torsi dan gaya $\mathrm{F}$ dianggap sama. Disamping itu mahasiswa beranggapan bahwa gaya yang sama besar bekerja dengan arah yang berlawanan akan saling meniadakan dengan tidak mempertimbangkan lengan gaya (posisi gaya dari pusat rotasi) yang dimiliki gaya tersebut. Sebagain yang lain terjadi kesalahan pada arah torsi, torsi yang berada pada posisi berlawanan dianggap berlawanan arah dengan tidak meninjau pusat rotasi.

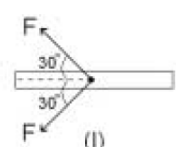

(1)

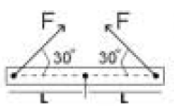

(II)

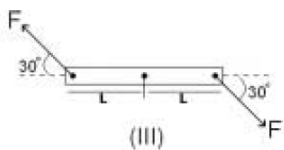

Gambar 3. Gambar soal konsep 3

Soal konsep hubungan torsi dan percepatan sudut pada soal No. 4. Mahasiswa tidak dapat menunjukan bagaimana pengaruh torsi terhadap percepatan sudut yang dialami suatu benda. Hal ini dipengaruhi oleh kemampuan mahasiswa menganalisis kedudukan torsi dalam percepatan sudut. Fakor lainnya berupa kemampuan mahasiswa menganalis momen inersia benda homogen kaku Soal konsep tersebut tersaji pada Gambar 4.
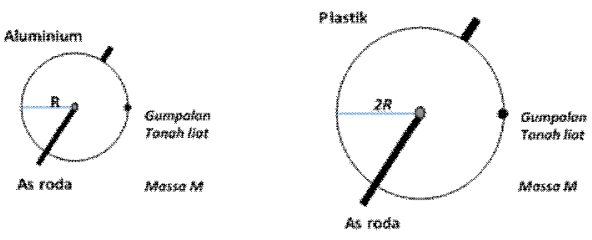

Gambar 4. Gambar soal konsep 4

Meninjau penguasaan konsep mahasiswa pada energi kinetik total. Dalam bahasan ini mahasiswa dituntut untuk mampu membedakan energi kinetik rotasi dan translasi dalam satu konsep atau menganalisis satu dari keduanya, yang mempengaruhi suatu gerak pada benda tegar. Kesalahan yang didapatkan bahwa mahasiswa tidak menunjukkan pengaruh gerak translasi dan rotasi pada suatu benda untuk menganalisis peranannya terhadap gerak. Bahkan terdapat mahasiswa yang tidak dapat membedakan energi kinetik rotasi dan energi kinetic translasi. Soal konsep tersaji pada Gambar 5.

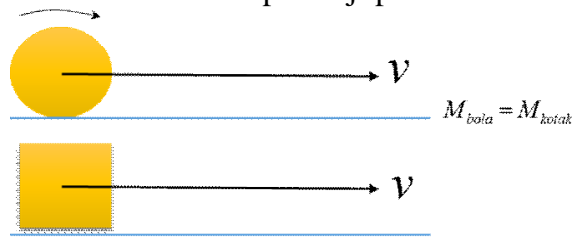

Gambar 5. Gambar soal konsep 5

Menganalisis benda yang bergelinding menuntut siswa untuk meninjau peranan momen inersia serta massa pada kondisi yang bersamaan. Pada kasus ini kekeliruan siswa tidak mampu mengintegrasikan antara gerak linier dan gerak rotasi untuk menyelesaikan soal konsep yang diberikan. Soal kasus tiga benda yang bergelinding terdapat siswa yang menyatakan bahwa 3 benda memiliki energi kinetik yang sama ketika berada pada $\mathrm{v}$ yang sama. Kesalahan lain berupa kemampuan mahasiswa menganalisis benda yang menyentuh tanah (dasar bidang miring) terlebih dahulu.

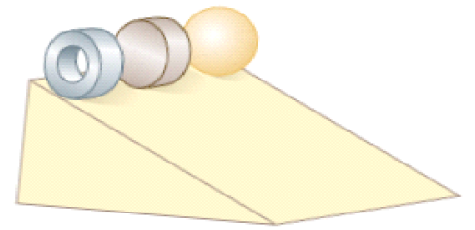

Gambar 6. Gambar soal konsep 6

Seoal konsep ke tujuh mahasiswa dituntut untuk menganalisis besaran momentum sudut dengan besaran momentum linier. Pada kasus ini siswa disajikan dua benda yang berotasi pada posisi yang berbeda seperti yang ditunjukkan pada gambar 7. mahasiswa tidak dapat menunjukkan peranan momen inersia terhadap momentum sudut, sehingga mahasiswa melakukan kesalahan dalam menyelesaikan soal konsep yang diberikan. Pada dasarnya konsep ini menekankan pada pengaruh posisi suatu benda dari pusat rotasi yang terdapat pada persamaan momen inersia, namun ketika mahasiwa tidak menguasai dengan baik konsep momen inersia sehingga kesalahan dalam menganalisis momentum sudut .

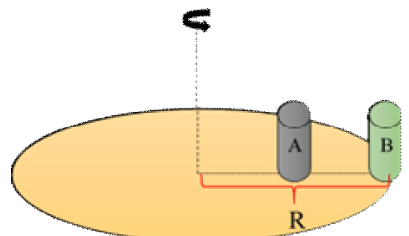

Gambar 7. Gambar soal konsep 7

Soal konsep ke delapan tentang hukum kekekalan momentum sudut menunjukkan seberapa baik mahasiswa mampu menguasai konsep rotasi secara utuh, sehingga mampu melihat peranan momen inersia, kecepatan sudut, serta kecepatan linier. Dari soal konsep yang ditunjukkan pada Gambar 8 yang diberikan terdapat analisis tentang perbedaan momen inersia satu benda dengan perubahan 
keadaan pada massa yang sama, pada kasus ini mengangkat contoh berupa penari sketer yang berputar pada empat posisi berbeda. Dari hasil analisis kesalahan yang didapatkan menunjukkan mahasiswa tidak memahami tentang momen inersia dan kecepatan sudut dalam tinjauan kekekalan momentum sudut.

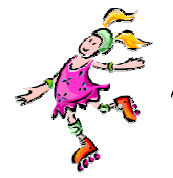

A

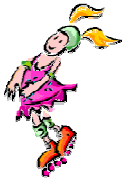

B

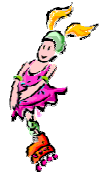

C

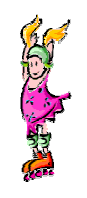

D
Gambar 8. Gambar soal konsep 8

Secara keseluruhan perbandingan penguasaan konsep mahasiswa berdasarkan pada indikator pembelajaran didapatkan data hasil jawaban siswa dengan grafik sebagai berikut :

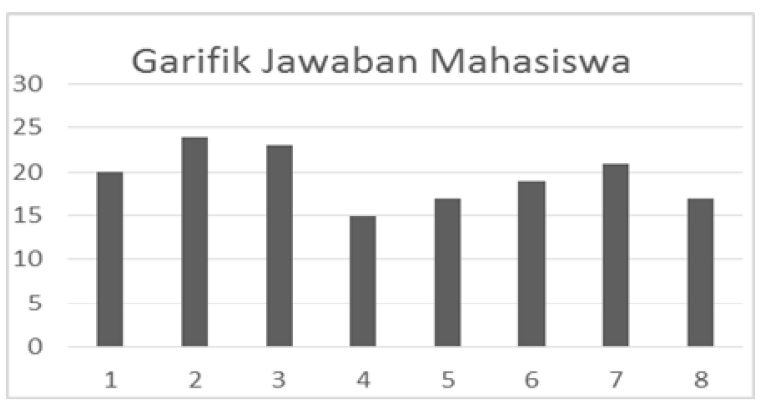

Keterangan :

$$
\begin{array}{ll}
1 & \text { : energi kinetik rotasi } \\
2 & \text { : momen inersia } \\
3 & \text { : torsi } \\
4 & \text { : hubungan torsi dan percepatan sudut } \\
5 & \text { : Energi kinetik total } \\
6 & \text { : Energi kinetik pada benda yang bergelinding } \\
7 & \text { : hubungan momentum sudut dan linier } \\
8 & \text { : hukum kekekalan momentum }
\end{array}
$$

Analisis keseluruhan dapat dinyatakan bahwa kesulitan yang didapatkan dari tes, Mahasiswa tidak menguasai perhitungan matematis untuk menunjukkan peranan momen inersia, kecepatan sudut torsi dan besaran lainnya sehingga terdapat kekeliruan yang mendasar pada hasil akhir penyelesaian soal penguasaan konsep

\section{KESIMPULAN}

Secara umum kesulitan yang dialami mahasiswa pada topik pembahasan rotasi dan momentum sudut dipengaruhi oleh penguasaan konsep pada gerak linier. Disampin itu kemampuan membedakan konsep gerak linier tersebut dalam gerak rotasi serta memahami besaran baru yang terdapat pada gerak rotasi.

\section{UCAPAN TERIMA KASIH}

Terimakasih pada rekan-rekan Pascasarjana pendidikan fisika universitas negeri malang yang telah mendukung penulisan artikel dengan judul analisis penguasaan konsep rotasi dan momentum sudut. Semoga hasil analisis ini memberikan gambaran umum tentang kesulitan yang dihadapi mahasiswa dalam membahas rotasi benda tegar dan momentum sudut

\section{PUSTAKA}

Artikel jurnal:

[1] Remoldini, Lorenzo G \& Chandralekha singh.. Student understanding of rotation and rolling motion concept. Physical Review Special Topiks- physics education research. 010102. 2005.

[2] Escudero, C, Marcao Antonio Moreira \& Concesa Caballero.A research on undergraduate students' conceptualizations of physics No.tions related to No.nsliding rotation motion. Lat. AM. J. Physcs education. Volume 3. No. 1. Januari 2009 (online). http://www.journal.lapen.org.mx

[3] Clark , Ian.2011. Formative Assessment: A Systematic and Artistic Process of Instruction or Supportin g School and Lifelong Learning : Canadian Journal Of Education 35, 2 (2012): 24- 40 @2011 Canadian Society for the St udy of Education.

[4] Gunawan, dkk. Model Pembelajaran Berbasis Multimedia Interaktif untuk Meningkatkan Penguasaan Konsep Calon Guru pada Materi Elastisitas. Jurnal Penelitian Pendidikan IPA. Vol 2 (1), 2008 pp 11-22.

Buku:

[5] Giancoli,. Fisika : jild 1 edisi kelima. Jakata : Erlangga. 2001

[6] Hallyday, D \& Robert Resnick. Fisika :jilid 1 edisi ketiga : Erlangga. 1998

[7] Jerwet, serwey. Penerjemah chriswansungkoNo. Fisika untuk sains.jakarta : graha ilmu 2009 